American J. of Engineering and Applied Sciences 2 (4): 603-610, 2009

ISSN 1941-7020

(C) 2009 Science Publications

\title{
A Novel Approach for Cooling Electronics Using a Combined Heat Pipe and Thermoelectric Module
}

\author{
Banjerd Saengchandr and Nitin V. Afzulpurkar \\ Asian Institute of Technology, School of Engineering and Technology, P.O. Box 4, \\ Klong Luang, Pathumthani 12120, Thailand
}

\begin{abstract}
The development of effective cooling systems for microprocessors, specifically for CPU and other computer chips, is greatly important due to growth of high speed performance chips, which operate at elevated heat rates. The same issues apply for adjacent units including RAM and HDD also contributing to overall generation of heat inside computer. Problem statement: Conventional cooling system for desktop PC has many problems, especially cooling performance. Lifespan of devices and reliable operation are largely dependent on junction temperature. Total power dissipation of recently introduced, new generation microprocessors had been increasing rapidly, pushing desktop system cooling technology close to its limits. Approach: Present research focused on a system for removal of dissipated heat that combined the advantages of heat pipe and thermoelectric modules. Proposed research presented a numerical analysis of a novel cooling system for electronics. Configuration studied concerns microprocessors and other computer ships. Simulations performed in this research were based on use of computational fluid dynamics and results obtained in terms of cooling efficiencies were compared to those of the traditional cooling. Heat resistance and temperature of each component were investigated in this modeling. Results: Lowest core temperature was found below $75^{\circ} \mathrm{C}$ and total thermal resistance of cooling system is $0.095^{\circ} \mathrm{C} / \mathrm{W}$. Conclusion/Recommendations: Proposed cooling systems had sufficient capacity for cooling $200 \mathrm{~W}$ heat dissipation. Temperature of proposed cooling system is lower than both existing cooling systems. Temperature of all components, CPU, heat pipe, TEC and heat sink were below $75^{\circ} \mathrm{C}$. Thermal resistance characteristic of a cooling system had a major effect on cooling performance.
\end{abstract}

Key word: Electronics cooling, heat pipe, thermoelectric cooling

\section{INTRODUCTION}

Since the current developments for high performance CPUs operating at higher speeds result in increased heat generation which, in turn, requires more efficient methods for heat dissipation. The development of effective cooling systems for microprocessors, specifically for the CPU and other computer chips, is greatly important due to the growth of high speed performance chips, which operate at elevated heat rates. The same issues apply for the adjacent units including the RAM and HDD also contributing to the overall generation of heat inside the computer. For the case of a desktop PC, heat is generated at a rate about $50-100 \mathrm{~W}$ at temperatures of $80-90^{\circ} \mathrm{C}^{[1]}$. Passive cooling systems such as heat pipe cooling systems are still being used because they are easy to construct and are of low cost. However, for high heat dissipation, it is close to its operational limit since the cooling system can no longer fit in the available enclosure. The heat dissipation capacity supporting from traditional passive cooling can coped with 50-160 W of heat dissipation. For Remote Heat Exchanger (RHE) systems, there are certain developments concerning the use of ordinary HP methods. Under air-cooling at a speed of $2 \mathrm{~m} \mathrm{sec}^{-1} \mathrm{HP}$ methods, it can transfer up to $50 \mathrm{~W}$ at a thermal resistance of about $1.3^{\circ} \mathrm{C} / \mathrm{W}$. While evaluating the qualities of most cooling systems, some of the other important parameters are: mass size, installation and cost. The conventional cooling system for a desktop PC reveals many problems, especially cooling performance. Moreover, the lifespan of devices and reliable operation is largely depends on the junction temperature. The total power dissipation of recently introduced, new generation microprocessors has been increasing rapidly, these pushing desktop system

Corresponding Author: Banjerd Saengchandr, Asian Institute of Technology, School of Engineering and Technology, P.O. Box 4, Klong Luang, Pathumthani 12120, Thailand 
Am. J. Engg. \& Applied Sci., 2 (4): 603-610, 2009

Table 1: The sample specifications of a $\mathrm{CPU}^{[3]}$

\begin{tabular}{|c|c|c|c|c|c|c|}
\hline & Fx-53 (S 940) & Fx-53 (S 939) & $3800+($ S 939) & $3500+($ S 939) & $3700+($ S 754) & $3400+($ S 754) \\
\hline L1 cache (total) & $128 \mathrm{~K}$ & $128 \mathrm{~K}$ & $128 \mathrm{~K}$ & $128 \mathrm{~K}$ & $128 \mathrm{~K}$ & $128 \mathrm{~K}$ \\
\hline L2 cache (exclusive) & $1 \mathrm{MB}$ & $1 \mathrm{MB}$ & $512 \mathrm{~K}$ & $512 \mathrm{~K}$ & $1 \mathrm{MB}$ & $1 \mathrm{MB}$ \\
\hline CPU core frequency & $2.4 \mathrm{GHz}$ & $2.4 \mathrm{GHz}$ & $2.4 \mathrm{GHz}$ & $2.2 \mathrm{GHz}$ & $2.4 \mathrm{GHz}$ & $2.2 \mathrm{GHz}$ \\
\hline CPU to memory controller & $2.4 \mathrm{GHz}$ & $2.4 \mathrm{GHz}$ & $2.4 \mathrm{GHz}$ & $2.2 \mathrm{GHz}$ & $2.4 \mathrm{GHz}$ & $2.2 \mathrm{GHz}$ \\
\hline Memory controller bus width & 128 bit & 128 bit & 128 bit & 128 bit & 64 bit & 64 bit \\
\hline Memory type & Registered & Unbuffered & Unbuffered & Unbuffered & Unbuffered & Unbuffered \\
\hline Compatable memoryspeeds & & \multicolumn{5}{|c|}{ PC1600, PC2100, PC2700 and PC3200 DDR } \\
\hline Hyper transport links & 1.0 & 1.0 & 1.0 & 1.0 & 1.0 & 1.0 \\
\hline Hyper transport spec (DDR) & $1.6 \mathrm{GHz}$ & $2.0 \mathrm{GHz}$ & $2.0 \mathrm{GHz}$ & $2.0 \mathrm{GHz}$ & $1.6 \mathrm{GHz}$ & $1.6 \mathrm{GHz}$ \\
\hline Packaging & Ceramic & Organic & Organic & Organic & Organic & Organic \\
\hline Fab location & & \multicolumn{5}{|c|}{ AMD's fab30 wafer fabrication facility in Dresden, Germany } \\
\hline Process technology & 0.13 (SOI) & 0.13 (SOI) & 0.13 (SOI) & 0.13 (SOI) & 0.13 (SOI) & 0.13 (SOI) \\
\hline Approximate transistor count & $105.9 \mathrm{M}$ & $105.9 \mathrm{M}$ & $68.5 \mathrm{M}$ & $68.5 \mathrm{M}$ & $105.9 \mathrm{M}$ & $105.9 \mathrm{M}$ \\
\hline Approximate die size (squared) & $193 \mathrm{~mm}$ & $193 \mathrm{~mm}$ & $144 \mathrm{~mm}$ & $144 \mathrm{~mm}$ & $193 \mathrm{~mm}$ & $193 \mathrm{~mm}$ \\
\hline Nominal voltage & $1.5 \mathrm{v}$ & $1.5 \mathrm{v}$ & $1.5 \mathrm{v}$ & $1.5 \mathrm{v}$ & $1.5 \mathrm{v}$ & $1.5 \mathrm{v}$ \\
\hline Max ambient case temp & $70^{\circ} \mathrm{C}$ & $70^{\circ} \mathrm{C}$ & $70^{\circ} \mathrm{C}$ & $70^{\circ} \mathrm{C}$ & $70^{\circ} \mathrm{C}$ & $70^{\circ} \mathrm{C}$ \\
\hline Max thermal power & $89 \mathrm{~W}$ & $89 \mathrm{~W}$ & $89 \mathrm{~W}$ & $89 \mathrm{~W}$ & $89 \mathrm{~W}$ & $89 \mathrm{~W}$ \\
\hline Max ICC (processor current) & $57.4 \mathrm{~A}$ & $57.4 \mathrm{~A}$ & $57.4 \mathrm{~A}$ & $57.4 \mathrm{~A}$ & $57.8 \mathrm{~A}$ & $57.8 \mathrm{~A}$ \\
\hline
\end{tabular}

cooling technology close to its limits. CPUs' core voltages, heat and power dissipation and temperature ratings are increasingly important aspects of PC architecture $^{[2]}$. In Table 1 it shows the example of a CPU specification with low thermal power and high ambient case temperature.

Numerous researches have been conducted to provide an optimum solution but so far there have been no significant investigations into PCs because of the function in different locations as well as at various ambient temperatures. During operation, the power consumption of the CPU shows how much heat is generated or dissipated because of defining the requirements of a suitable cooling system. In Table 2 it shows the example of power consumption of a CPU in an idle test and under load test. The idle test is running the computer with only the operating system without other software. The under load test is defined as running a compute-intensive test application that maximizes processor usage and power consumption.

The performance of the cooling system is measured by the Coefficient Of Performance (COP), as described with following equations:

$\mathrm{COP}_{\text {cooling }}=\frac{\mathrm{Q}_{\text {cold }}}{\mathrm{Q}_{\text {hot }}-\mathrm{Q}_{\text {cold }}}=\frac{\mathrm{T}_{\text {cold }}}{\mathrm{T}_{\text {hot }}-\mathrm{T}_{\text {cold }}}$

Similarly:

$\mathrm{COP}_{\text {heating }}=\frac{\mathrm{Q}_{\text {hot }}}{\mathrm{Q}_{\text {hot }}-\mathrm{Q}_{\text {cold }}}=\frac{\mathrm{T}_{\text {hot }}}{\mathrm{T}_{\text {hot }}-\mathrm{T}_{\text {cold }}}$

Where:

$\mathrm{Q}_{\text {cold }}=$ The heat taken in by the cold heat reservoir

$\mathrm{Q}_{\text {hot }}=$ The heat given off by the hot heat reservoir

$\mathrm{T}_{\text {hot }}=$ The temperature of hot reservoir

$\mathrm{T}_{\text {cold }}=$ The temperature of cold reservoir
Table 2: The power comparison of CPU in an idle test and under load test ${ }^{[4]}$

\begin{tabular}{|c|c|c|c|c|c|}
\hline \multicolumn{3}{|c|}{ Power consumption } & \multicolumn{3}{|c|}{ Thermal out put } \\
\hline Idle & CPU max & $\begin{array}{l}\text { CPU } \\
\text { +disk max }\end{array}$ & Idle & CPU max & $\begin{array}{l}\text { CPU } \\
\text { +disk max }\end{array}$ \\
\hline 04 & V $244 \mathrm{~W}$ & $247 \mathrm{~W}$ & $694 \mathrm{BTU} / \mathrm{h}$ & $830 \mathrm{BTU} / \mathrm{h}$ & $840 \mathrm{BTU} / \mathrm{h}$ \\
\hline
\end{tabular}

Xserve (early 2008): Configration: one $2.8 \mathrm{GHz}$ quad-core intel xeonprocessor, single 80 GB 7200RPM, Stata apple drive module, 2 GB RAM (2×1 GB $800 \mathrm{MHz}$ DDR2 ECC fully buffered. DIMMs), ATI radeon X1300 graphics with 64 MB RAM, no PCI cards

The inherent benefit of the heat-pipe cooling method is the transference of heat with minimum heat loss; the advantage of the thermoelectric cooler is high efficiency of the cooling system at the cold side ${ }^{[5]}$. The moisture condensed at the cold side is a disadvantage of the thermoelectric cooler. To minimize or eliminate this problem, additional equipment ${ }^{[6]}$, which can be implemented by combining the thermoelectric cooler (as a remote heat exchanger) with a heat pipe is required. The system consists of the heat pipe, thermoelectric cooler unit, heat sink and fan. The idea of this proposed design is to produce a cooling system which can transfer heat through the heat sink with uniform distribution since non-uniform heat distribution affects the cooling performance.

\section{MATERIALS AND METHODS}

The structure of the system can be expressed in terms of the heat resistance circuit as shown in Fig. 1. The specifications for which this solution is proposed are showed in Table 3.

The proposed design and the assembly of the combined heat pipe and thermoelectric unit follows the thermal resistance circuit as shown in Fig. 1. The evaporating part of the heat pipe is glued to the surface 


$$
\begin{aligned}
& \mathrm{R}_{\mathrm{jc}} \quad \mathrm{R}_{\mathrm{cHPev}} \mathrm{R}_{\mathrm{HP}} \mathrm{R}_{\text {HPTEC }} \mathrm{R}_{\mathrm{TEC}} \mathrm{R}_{\mathrm{TECs}} \mathrm{R}_{\mathrm{sAmb}}
\end{aligned}
$$

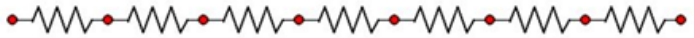

$$
\begin{aligned}
& { }_{7} \mathrm{~T}_{\mathrm{J}} \mathrm{T}_{\mathrm{C}} \mathrm{T}_{\text {HPev }} \mathrm{T}_{\text {HPcon }} \mathrm{T}_{\mathrm{TEC} \text { cold }} \mathrm{T}_{\text {TEChot }} \mathrm{T}_{\mathrm{s}} \mathrm{T}_{\text {Amb }}
\end{aligned}
$$

Fig. 1: Thermal resistance circuit of cooling system

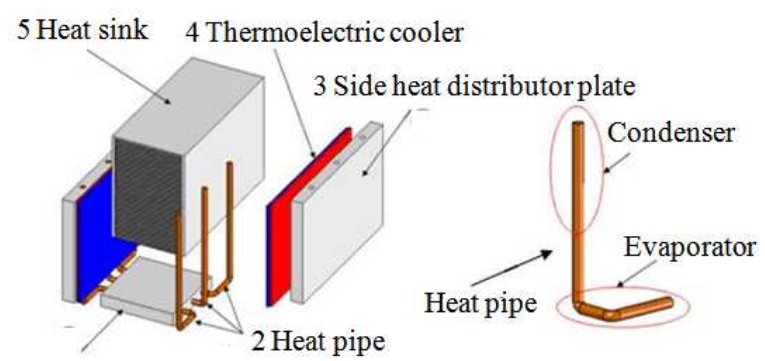

1 Bottom heat distributor plate

Fig. 2: 3D assembly of cooling system

Table 3: The specification for which this solution is proposed

\begin{tabular}{ll}
\hline CPU heat dissipation & $0-200 \mathrm{~W}$ \\
Ambient temperature & 40 \\
Core temperature & $100^{\circ} \mathrm{C}$ \\
Die size & $<200 \mathrm{~mm}^{2}$ \\
\hline
\end{tabular}

of the CPU where the heat is generated. The condensing part of the heat pipe is glued to the cold side of thermoelectric cooler and the heat sink is glued at hot side. The fan was connected to the heat sink. The schematic view of the assembly is shown in Fig. 2. The heat pipe (2), the side heat distributor plate (3) and bottom heat distributor plate (1) were assembled with interferent fits but the assembly of the thermoelectric unit (4) and heat distributor plate (3) were done by using thermal grease or another interface medium. The assembly of the heat sink also uses thermal grease. The cooling system is put on to the chip next to the bottom heat distributor plate 1 .

Thermoelectric selection: Thermoelectric coolers are solid state heat pumps based on the Peltier Effect, a typical junction phenomenon. An electrical current produces heating or cooling at the junction of two dissimilar metals depending upon the direction of the current flow. The heat absorbed or created at the junction is proportional to the electric current. The proportional constant is known as the Peltier coefficient. To determine the properties of a suitable thermoelectric device, the following equations are taken into consideration ${ }^{[7]}$.

Heat pumped at cold surface:

$$
\mathrm{Q}_{\mathrm{c}}=2 \mathrm{~N}\left[\alpha \cdot \mathrm{I} \cdot \mathrm{T}_{\mathrm{c}}-\left(\frac{\mathrm{I}^{2} \cdot \rho}{2 \mathrm{G}}\right)-\mathrm{k} \cdot \mathrm{DT} \cdot \mathrm{G}\right]
$$

Voltage:

$$
\mathrm{V}=2 \mathrm{~N}\left[\frac{\mathrm{I} \cdot \rho}{\mathrm{G}}+\alpha \cdot \mathrm{DT}\right]
$$

Maximum current:

$$
\mathrm{I}_{\max }=\left(\frac{\mathrm{kG}}{\alpha}\right) \cdot\left[(1+(2 \mathrm{Z} \cdot \mathrm{T} \cdot \mathrm{h}))^{1 / 2}-1\right]
$$

Optimum current:

$$
I_{\text {opt }}=\frac{k \cdot D T \cdot G\left(1+\left(1+Z \cdot T_{\text {ave }}\right)^{1 / 2}\right)}{\alpha \cdot T_{\text {ave }}}
$$

Optimum COP (calculated at I opt):

$$
\mathrm{COP}_{\text {opt }}=\left(\frac{\mathrm{T}_{\text {ave }}}{\mathrm{DT}}\right) \cdot\left[\frac{\left(1+\mathrm{Z} \cdot \mathrm{T}_{\text {ave }}\right)^{1 / 2}-1}{\left(1+\mathrm{Z} \cdot \mathrm{T}_{\text {ave }}\right)^{1 / 2}+1}\right]^{-1 / 2}
$$

Maximum DT with $\mathrm{Q}=0$ :

$$
\mathrm{DT}_{\max }=\mathrm{Th}-\left[\frac{(1+2 \mathrm{Z} \cdot \mathrm{Th})^{1 / 2}-1}{\mathrm{Z}}\right]
$$

Where:

$\mathrm{Th}=$ Hot side temperature (Kelvin)

Tc $=$ Cold side temperature (Kelvin)

DT $=$ Th-Tc (Kelvin)

Tave $=1 / 2(\mathrm{Th}+\mathrm{Tc})($ Kelvin$)$

$\mathrm{G} \quad=$ Area/length of TE element $(\mathrm{cm})$

$\mathrm{N}=$ Number of thermocouples

$\mathrm{I}=$ Current $(\mathrm{amps})$

$\mathrm{COP}=$ Coefficient of performance $(\mathrm{Qc} / \mathrm{IV})$

$\alpha=$ Seebeck coefficient (volts/Kelvin)

$\rho \quad=$ Resistivity $(\mathrm{ohm} \mathrm{cm})$

$\mathrm{k} \quad=$ Thermal conductivity (Watt/(cm Kelvin) $)$

$\mathrm{Z} \quad=$ Figure of merit $\left(\mathrm{a}^{2} /(\mathrm{r} \mathrm{k})\right)($ Kelvin-1)

$\mathrm{S}=$ Device seebeck voltage (2aN) (Volts/Kelvin)

$\mathrm{R}=$ Device electrical resistance $(2 \mathrm{r} N / \mathrm{G})(\mathrm{Ohms})$

$\mathrm{K}$ = Device thermal conductance $(2 \mathrm{kNG})$ (Watt/Kelvin)

Since the system is to be used for cooling equipment which dissipates $200 \mathrm{~W}$, the power of the heat pump at the cold side of the Thermo-Electric Cooler (TEC) must also be $200 \mathrm{~W}$. In this study, the TEC cold side temperature was kept at $20^{\circ} \mathrm{C}$, the voltage supply at $12 \mathrm{~V}$ and the ambient temperature at $40^{\circ} \mathrm{C}$. In Table 2 it shows the performance of the TEC using the above values with Eq. 3-8. 


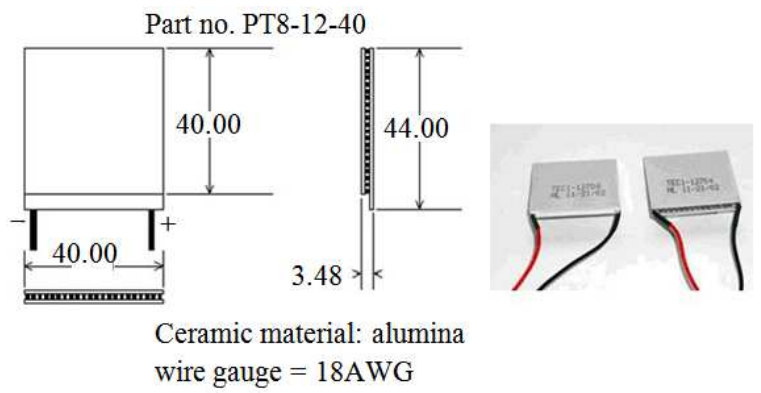

Fig. 3: Thermoelectric unit ${ }^{[7]}$

The selected thermoelectric device is a multiple set of p- and n-type semiconductors. In this study, the result of calculation for the thermoelectric couple is 635 couples, with an estimated surface area of $192 \mathrm{~cm}^{2[7]}$. The commercial thermoelectric cooler as shown in Fig. 3 was chosen.

Heat pipe selection: For its construction, three different regions within the body of the heat pipe were considered. These are the evaporating zone, where the working fluid is evaporated, the condensing zone, where the working fluid is condensed and the adiabatic zone, located between the evaporating zone and the condensing zone where there is very little physical change in the fluid ${ }^{[8]}$. In this research, Jaroslaw Legierski's heat pipe design is implemented by using a water heat pipe of $200 \mathrm{~mm}$ length and $4 \mathrm{~mm}$ diameter ${ }^{[9]}$. In Fig. 4 it shows the 3D design and the assembly of the selected heat pipe with its heat distributor plates. The detail dimensions are given in Table 4.

The power transmitted through the pipe is evaluated as:

$$
\mathrm{P}=\mathrm{m} \cdot \mathrm{c}_{\mathrm{s}} \cdot \frac{\mathrm{T}_{\mathrm{c},(@ \text { time })}-\mathrm{T}_{\mathrm{c},(@ \text { time }=0)}}{\mathrm{t}}
$$

Where:

$$
\begin{array}{ll}
\mathrm{m} & =\text { The water mass in cold container }(\mathrm{mL}) \\
\mathrm{Cs} & =\text { The specific heat of water }\left(\mathrm{j} / \mathrm{g}{ }^{\circ} \mathrm{C}\right) \\
\mathrm{T}_{\mathrm{c}(@ \text { time })} & =\text { Temperature at any time }\left({ }^{\circ} \mathrm{C}\right) \\
\mathrm{T}_{\mathrm{c}(@ \text { time }=0)} & =\text { Temperature at time }=0\left({ }^{\circ} \mathrm{C}\right) \\
\mathrm{t} & =\text { Total time }(\mathrm{sec})
\end{array}
$$

The effective thermal conductivity of the pipe is expressed by Eq. ${ }^{[9]}$ :

$$
\lambda=-\phi \frac{\mathrm{L}_{\text {eff }}}{\Delta \mathrm{T}}
$$

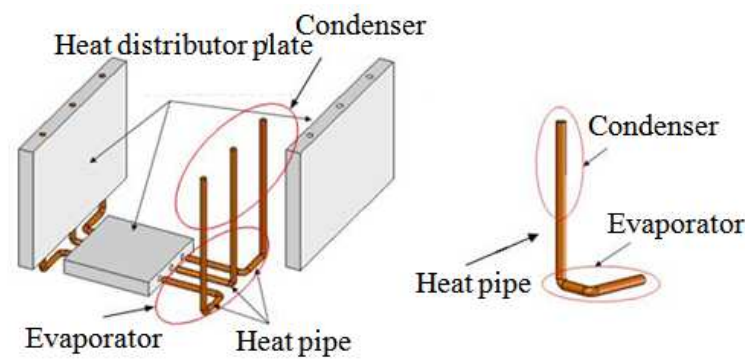

Fig. 4: Heat pipe assembly, detail dimensions are given in Table 4

Table 4: Initial feasibility study of heat sink

\begin{tabular}{ll}
\hline CHIP specification & Power dissipation $200 \mathrm{~W}$ \\
Base thickness & $1-5 \mathrm{~mm}$ \\
Heat sink dimensions & $\mathrm{W} \times \mathrm{L} \times \mathrm{H}=120 \times 160 \times 60 \mathrm{~mm}$ \\
Fin thickness & $0.1-1 \mathrm{~mm}$ \\
Number of fins & $30-90$ \\
Fin height & $40-60 \mathrm{~mm}$ \\
Fin airflow & $20 \mathrm{CFM}$ entering at $40^{\circ} \mathrm{C}$ \\
\hline
\end{tabular}

$\mathrm{L}_{\text {eff }}=\frac{\mathrm{L}_{\mathrm{c}}}{2}+\mathrm{L}_{\mathrm{A}}+\frac{\mathrm{L}_{\mathrm{E}}}{2}$

The heat resistance of the heat pipe can be expressed by:

$\mathrm{R}_{\mathrm{HP}}=\frac{\Delta \mathrm{T}}{\mathrm{P}_{\mathrm{T}}}$

Where:

$\lambda=$ Thermal conductivity

$\phi \quad=$ Heat flux along the pipe

$\Delta \mathrm{T}=$ Temperature gradient

$\mathrm{L}_{\text {eff }}=$ Effective heat pipe length

Lc $=$ Condenser length

$\mathrm{L}_{\mathrm{A}}=$ Adiabatic length

$\mathrm{L}_{\mathrm{E}}=$ Evaporator length

$\mathrm{P}_{\mathrm{T}}=$ Power transport to cold container

Heat sink selection: For the design of a heat sink, computational techniques (lumped FEA and CFD) are recommended ${ }^{[10]}$. The heat sink selection is based on the following requirements; $200 \mathrm{~W}$ of heat dissipation from the $\mathrm{CHIP}, 40^{\circ} \mathrm{C}$ ambient temperature and maximum junction temperature as $100^{\circ} \mathrm{C}$. Because of space limitation inside the computer enclosure, a fixed volume heat sink was used. The initial feasibility study to determine an optimum heat sink design is shown in Table 4.

The objective of the optimization is to minimize the core temperature of the heat source. The variable parameters are the base thickness, fin thickness, the 
number of fins and fin height and the heat sink which gives lowest core temperature was chosen. The results of the optimization following implementation of "COOLIT" software are tabulated in Table 5 and a 3Dillustration of optimum heat sink is shown in Fig. 5.

The simulation conditions: "COOLIT" simulation software is used to evaluate the proposed cooling system. While the boundary conditions for the simulation were classified into two groups. The first group is the enclosure, consisting of the enclosure wall, vents and fan and the second group is inside the enclosure, consisting of the computer components as shown in Fig. 6.

The list of components are:

- Enclosure dimension $350 \times 180 \times 400 \mathrm{~mm}$ (steel)

- Enclosure fan (speed $4300 \mathrm{rpm}$ Air flow rate $120 \mathrm{~L}$ $\min ^{-1}$, noise $21 \mathrm{~dB}$ )

- Power supply $450 \mathrm{~W}$

- CD ROM

- CPU $200 \mathrm{~W}$ core size $21 \times 21 \mathrm{~mm}$

- CHIPSET $20 \mathrm{~W}$ core size $8 \times 8 \mathrm{~mm}$

- VGA card $20 \mathrm{~W}$

- Audio card $20 \mathrm{~W}$

- Data acquisition card $20 \mathrm{~W}$

- Hard disk $30 \mathrm{~W}$

- Floppy disk drive

Other components, which do not dissipate significant amounts of heat, are neglected in simulation process. The details of the components are shown in Table 6.

Table 5: The optimization result

\begin{tabular}{ll}
\hline CHIP specification & Power dissipation $200 \mathrm{~W}$ \\
Base thickness & $4.75 \mathrm{~mm}$ \\
Heat sink dimensions & $\mathrm{W} \times \mathrm{L} \times \mathrm{H}=120 \times 160 \times 51 \mathrm{~mm}$ \\
Fin thickness & $0.57 \mathrm{~mm}$ \\
Number of fins & 81 \\
Fin height & $41.3 \mathrm{~mm}$ \\
\hline
\end{tabular}

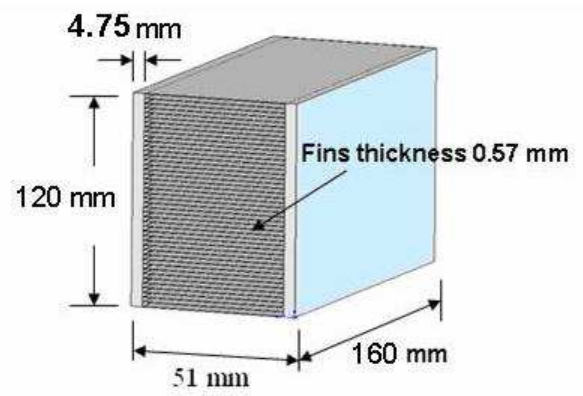

Fig. 5: Dimensions of heat sink

\section{Enclosure:}

- Dimension: $\mathrm{X}=350 \mathrm{Y}=180 \mathrm{Z}=400 \mathrm{~mm}$ (steel wall patch)

- Enclosure fan: Speed $4300 \mathrm{rpm}$, Air flow rate $120 \mathrm{~L} \mathrm{~min}^{-1}$, Noise $21 \mathrm{~dB}$

Gravity factor: $\mathrm{Y}=9.81$ :

- $\quad \mathrm{X}$ min: Steel wall

- X max: Steel wall

- Y min: Steel wall

- Y max: Steel wall

- $\mathrm{Z}$ min: Fan

- $\mathrm{Z}$ max: Vent

Vent properties:

- Perforate plate

- Percent open 0.5

- Thermal conductivity $0.026 \mathrm{~W} \mathrm{mK}^{-1}$

- Emissivity 0.9

To simulate the model under transient conditions, the required time was set to $100 \mathrm{~min}$ and the time step was $0.005 \mathrm{~min}$ and 20,000 steps. To monitor the temperature of the system, temperature sensors were attached to each component. The dissipation power was applied, as shown in Fig. 7 and the ambient temperature was set at $40^{\circ} \mathrm{C}$.
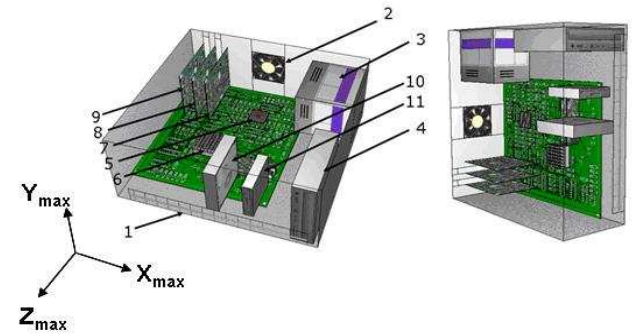

Fig. 6: Computer box

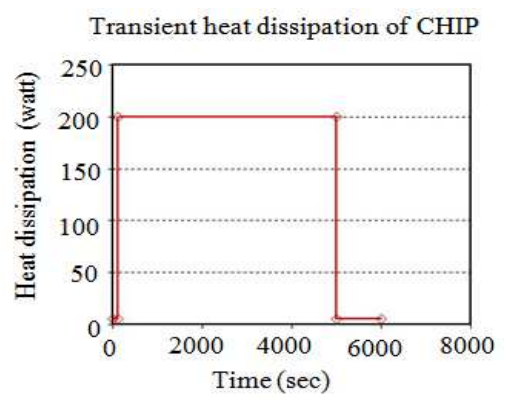

Fig. 7: Transient heat dissipation 
Am. J. Engg. \& Applied Sci., 2 (4): 603-610, 2009

Table 6: Properties of interior component

\begin{tabular}{|c|c|}
\hline Component & Properties \\
\hline \multirow[t]{5}{*}{ Chip } & Power $200 \mathrm{~W}$ \\
\hline & Core size $21 \times 21 \mathrm{~mm}$ \\
\hline & Emissivity 0.9 \\
\hline & $\mathrm{R}$ Junction to board $0.5^{\circ} \mathrm{C} / \mathrm{W}$ \\
\hline & $\mathrm{R}$ Junction to case $0.5^{\circ} \mathrm{C} / \mathrm{W}$ \\
\hline \multirow[t]{4}{*}{ PCB } & Material FR4 \\
\hline & Conductivity $0.3 \mathrm{~W} \mathrm{mK}^{-1}$ \\
\hline & Density $1200 \mathrm{~kg} \mathrm{~m}^{-3}$ \\
\hline & Heat capacity $880 \mathrm{~J} \mathrm{kgK}^{-1}$ \\
\hline \multirow[t]{6}{*}{ Heat sink } & Dimension $X=51, Y=120, Z=160$ \\
\hline & Material copper (391.162) \\
\hline & Fin thickness $0.57 \mathrm{~mm}$ \\
\hline & Number of fins 58 \\
\hline & Fin height $41.3 \mathrm{~mm}$ \\
\hline & Base thickness $4.75 \mathrm{~mm}$ \\
\hline \multirow{2}{*}{ Heat pipe } & Diameter $4 \mathrm{~mm}$, length $200 \mathrm{~mm}$ \\
\hline & $\begin{array}{l}\text { Conductivity } 15,000-30,000 \mathrm{~W} \mathrm{mK}^{-1} \\
\text { (time dependent) heat distribution } \\
\text { plate } \mathrm{W} \times \mathrm{L} \times \mathrm{H}=120 \times 160 \times 8 \mathrm{~mm}\end{array}$ \\
\hline \multirow[t]{6}{*}{ Thermoelectric cooler } & Heat pump at cold side $\mathrm{Q}_{\mathrm{c}} 200 \mathrm{~W}$ \\
\hline & Voltage $50 \mathrm{~V}$ max current $9.39 \mathrm{~A}$ \\
\hline & Optimum current $2.51 \mathrm{~A}$ \\
\hline & Coefficient of Performance COP 1.17 \\
\hline & Max differential temperature $77.56^{\circ} \mathrm{C}$ \\
\hline & Number of couples 635 \\
\hline \multirow[t]{2}{*}{ Interface materials } & Arctic silver (thermal resistance \\
\hline & $\left.0.0045^{\circ} \mathrm{C} / \mathrm{W}\right)$ \\
\hline \multirow[t]{3}{*}{ Fan } & Speed 4300rpm \\
\hline & Air flow rate $120 \mathrm{~L} \mathrm{~min}^{-1}$ \\
\hline & Noise $21 \mathrm{~dB}$ air pressure $18.6 \mathrm{~Pa}$ \\
\hline
\end{tabular}

\section{RESULTS}

The simulation was carried out for temperature measurement using COOLIT $6.0 \mathrm{~V}$ software. The measurements of temperature are showed in Fig. 8. The results of the study are shown in Fig. 9 and 10. The response graph, Figure shows that the core temperature reached $74^{\circ} \mathrm{C}$ after $15 \mathrm{~min}$ of the system's heat dissipation.

The highest temperature at the chip was found to be stable and below $75^{\circ} \mathrm{C}$. After the dissipation power turning off the core temperature reduces to ambient temperature within $18 \mathrm{~min}$. When switched off, the components behave differently. During operation the heat pipe temperature tends to be proportional to the CPU temperature but the TEC and heat sink temperature increase slowly. This suggests that the heat pipe has very good heat transfer but that for the heat sink and TEC depends on the flow rate of the fan. When the temperature of heat pipe is considered, the gradient of the graph means that the heat-transferring ability of the heat pipe was good enough to cope with the heat dissipation of the order of $200 \mathrm{~W}$. The ambient temperature was influenced by heat sink, when ambient temperature rises the surrounding pressure is high and

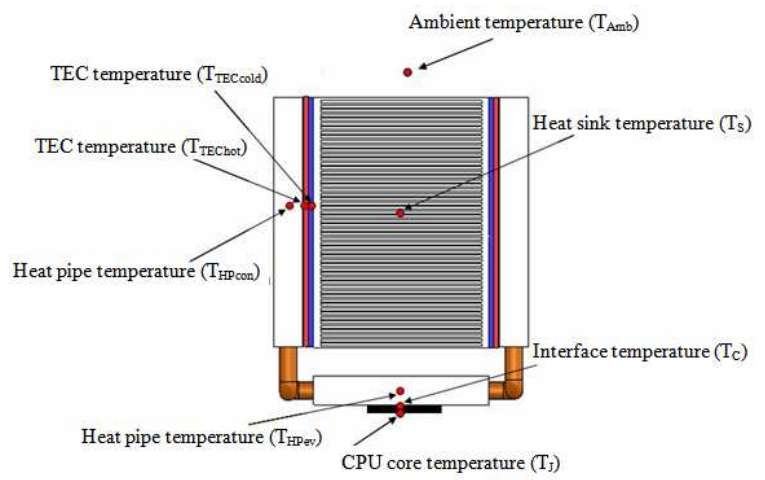

Fig. 8: Temperature measurement

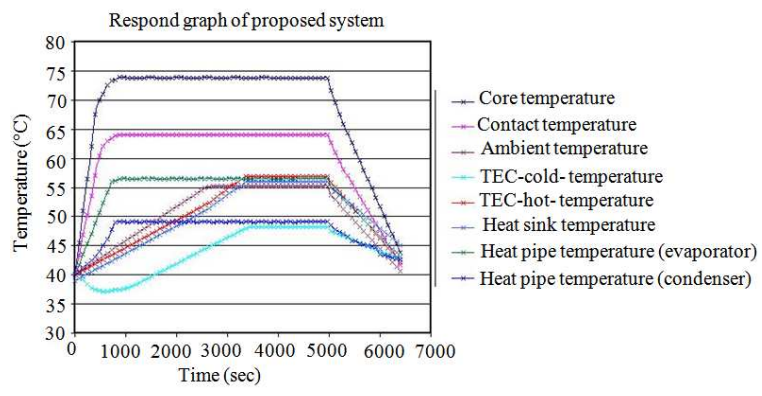

Fig. 9: Response graph of cooling system

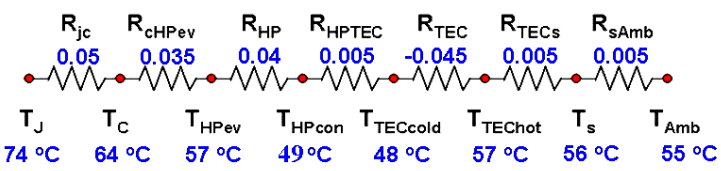

Fig. 10: Thermal circuit of cooling system

the removal of heat from the heat sink is difficult. To solve this problem, a high volume flow rate fan was used. However, this is noisy.

The measurements results are:

$\begin{array}{ll}\mathrm{TAmb} & =55^{\circ} \mathrm{C} \\ \mathrm{Ts} & =56^{\circ} \mathrm{C} \\ \mathrm{T}_{\mathrm{TEChot}} & =57^{\circ} \mathrm{C} \\ \mathrm{T}_{\text {TECcole }} & =48^{\circ} \mathrm{C} \\ \mathrm{T}_{\text {HPcon }} & =49^{\circ} \mathrm{C} \\ \mathrm{T}_{\text {HPev }} & =57^{\circ} \mathrm{C} \\ \mathrm{Tc} & =64^{\circ} \mathrm{C} \\ \mathrm{Tj} & =74^{\circ} \mathrm{C}\end{array}$

Equation 13 was used to determine the thermal resistances of each part and the cooling of the system. During operation, the equation describing the total thermal resistance of the proposed system is: 
Am. J. Engg. \& Applied Sci., 2 (4): 603-610, 2009

$$
\begin{aligned}
& \mathrm{R}_{\mathrm{ja}}=\mathrm{R}_{\mathrm{jc}}+\mathrm{R}_{\mathrm{cHPev}}+\mathrm{R}_{\mathrm{HP}}+\mathrm{R}_{\text {HPTEC }} \\
& +\mathrm{R}_{\mathrm{TEC}}+\mathrm{R}_{\mathrm{TECs}}+\mathrm{R}_{\mathrm{sAmb}}=\frac{\left(\mathrm{T}_{\mathrm{j}}-\mathrm{T}_{\mathrm{a}}\right)}{\mathrm{Q}}
\end{aligned}
$$

$\mathrm{T}_{\mathrm{a}}$ depends on the operating environment. Additionally $\mathrm{T}_{\mathrm{j}}$ and $\mathrm{Q}$ are normally provided by the manufacturer.

The thermal resistances of each part of the cooling system were calculated from the above result. These values are given below:

- $\quad$ Resistance of junction $(\mathrm{Rjc})=0.05^{\circ} \mathrm{C} / \mathrm{W}$

- Interface resistance $\left(\mathrm{R}_{\mathrm{cHPev}}\right)=0.035^{\circ} \mathrm{C} / \mathrm{W}$

- Heat pipe resistance $\left(\mathrm{R}_{\mathrm{HP}}\right)=0.04^{\circ} \mathrm{C} / \mathrm{W}$

- Thermal resistance heat pipe to TEC

- $\left(\mathrm{R}_{\text {HPTEC }}\right)=0.005^{\circ} \mathrm{C} / \mathrm{W}$

- $\quad$ TEC resistance $\left(\mathrm{R}_{\mathrm{TEC}}\right)=-0.045^{\circ} \mathrm{C} / \mathrm{W}$

- Thermal resistance, TEC to heat sink

- $\left(\mathrm{R}_{\mathrm{TECs}}\right)=0.005^{\circ} \mathrm{C} / \mathrm{W}$

- Heat sink resistance $(\mathrm{RsAmb})=0.005^{\circ} \mathrm{C} / \mathrm{W}$

- Total resistance $(\mathrm{Rja})=0.095^{\circ} \mathrm{C} / \mathrm{W}$

- Time required for the system to reach maximum temperature $=1400 \mathrm{sec}$

- Time required for the system to cool after turning off the heat source $=1110 \mathrm{sec}$

\section{DISCUSSION}

The other two commercially cooling systems are simulated using the same conditions. The results were compared with the proposed cooling system as shown in Fig. 11 and Table 7.

\begin{tabular}{|c|c|c|c|}
\hline Thermal resistance & $\begin{array}{l}\text { Heat pipe } \\
\text { cooling } \\
\left({ }^{\circ} \mathrm{C} / \mathrm{W}\right)\end{array}$ & $\begin{array}{l}\text { TEC } \\
\text { cooling } \\
\left({ }^{\circ} \mathrm{C} / \mathrm{W}\right) \\
\end{array}$ & $\begin{array}{l}\text { Combined } \\
\text { cooling } \\
\left({ }^{\circ} \mathrm{C} / \mathrm{W}\right)\end{array}$ \\
\hline $\begin{array}{l}\text { Thermal resistance of } \\
\text { junction to contact } \\
\text { material (Rjc) }\end{array}$ & 0.030 & 0.005 & 0.050 \\
\hline $\begin{array}{l}\text { Interface resistance } \\
\left(\mathrm{R}_{\mathrm{cHPev}}\right),\left(\mathrm{R}_{\mathrm{cTEC}}\right)\end{array}$ & 0.065 & 0.095 & 0.035 \\
\hline $\begin{array}{l}\text { Heat pipe resistance } \\
\left(\mathrm{R}_{\mathrm{HP}}\right)\end{array}$ & 0.025 & -- & 0.040 \\
\hline $\begin{array}{l}\text { Thermal resistance of } \\
\text { heat pipe to heat sink } \\
\left(\mathrm{R}_{\mathrm{HPs}}\right)\end{array}$ & 0.020 & -- & -- \\
\hline $\begin{array}{l}\text { Thermal resistance, heat } \\
\text { pipe to TEC }\left(\mathrm{R}_{\text {HPTEC }}\right)\end{array}$ & -- & -- & 0.005 \\
\hline TEC resistance $\left(\mathrm{R}_{\mathrm{TEC}}\right)$ & -- & -0.06 & -0.045 \\
\hline $\begin{array}{l}\text { Thermal resistance, TEC } \\
\text { to heat sink }\left(\mathrm{R}_{\mathrm{TECS}}\right)\end{array}$ & -- & 0.025 & 0.005 \\
\hline $\begin{array}{l}\text { Heat sink resistance } \\
\text { (Rsa) }\end{array}$ & 0.050 & 0.23 & 0.005 \\
\hline Total resistance $(\mathrm{Rja})$ & 0.190 & 0.295 & 0.095 \\
\hline $\begin{array}{l}\text { Time required for the } \\
\text { system to reach maximum } \\
\text { temperature (Rising) }\end{array}$ & $1541 \mathrm{sec}$ & $1400 \mathrm{sec}$ & $720 \mathrm{sec}$ \\
\hline $\begin{array}{l}\text { Time required for the } \\
\text { system to cooling after } \\
\text { off dissipation (falling) }\end{array}$ & $1608 \mathrm{sec}$ & $1100 \mathrm{sec}$ & $1440 \mathrm{sec}$ \\
\hline
\end{tabular}

Table 7: The comparison of thermal resistance
The highest core temperature was found to be $133^{\circ} \mathrm{C}$ with the thermoelectric cooling system and lowest at $74^{\circ} \mathrm{C}$ with the proposed cooling system. The ambient temperature of each cooling system, measured between the heat sink and enclosure fan, was increased. The highest was found to be $79^{\circ} \mathrm{C}$ for the TEC cooling system and the lowest $55^{\circ} \mathrm{C}$ for the proposed cooling system. The temperature difference between the core and heat sink of each cooling system was found to be $28^{\circ} \mathrm{C}$ (heat pipe), $13^{\circ} \mathrm{C}$ (TEC) and $18^{\circ} \mathrm{C}$ for the proposed cooling system. The characteristic of the separate cooling systems was totally different to the proposed cooling system as shown in Fig. 12. The thermal resistances of both existing cooling systems are similarly, i.e., an increase after heat dissipation. Such characteristic indicates that existing cooling systems lack cooling ability because of the rising of thermal resistance when heat dissipated.

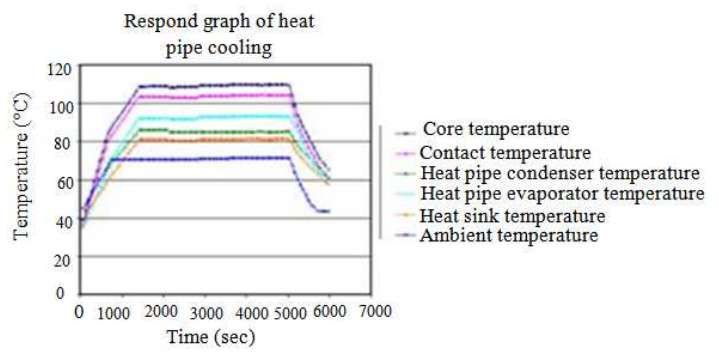

(a)

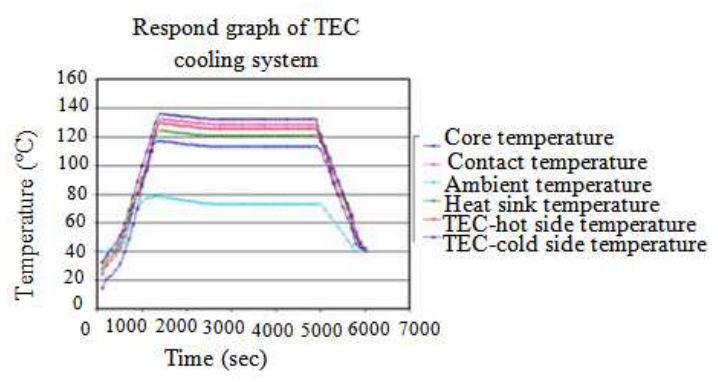

(b)

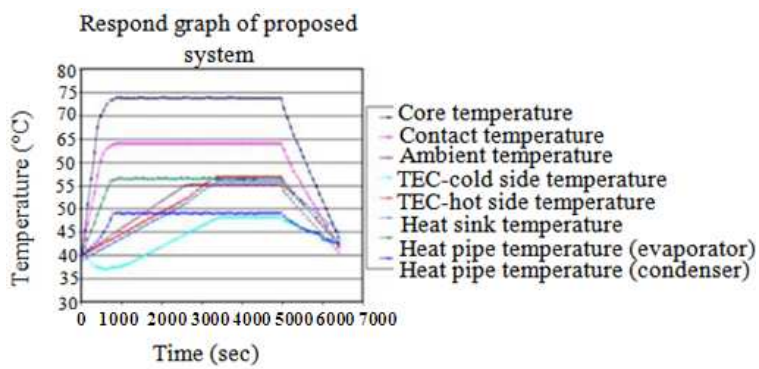

(c)

Fig. 11: Comparison of three systems; (a): Heat pipe cooling system; (b): TEC cooling system; (c): Proposed cooling system 


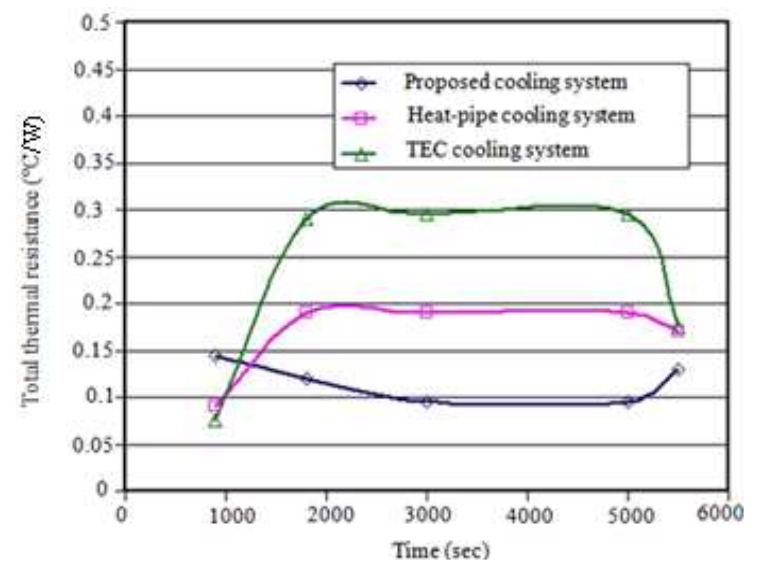

Fig. 12: Thermal behavior of cooling system

For the combined cooling system the resistance characteristic is opposite, i.e., the resistance decreased after heat dissipation. Such behavior makes the combined cooling system a better method of heat transfer from a heat source to ambient because of the cooling system has less heat resisting during operation.

\section{CONCLUSION}

The simulation model has shown that:

- The proposed cooling systems have sufficient capacity for cooling $200 \mathrm{~W}$ heat dissipation

- The temperature of the proposed cooling system is lower than both existing cooling systems. The temperature of all components, i.e. the $\mathrm{CPU}$, heat pipe, TEC and heat sink were below $75^{\circ} \mathrm{C}$

- The thermal resistance characteristic of a cooling system has a major effect on cooling performance

- Both existing cooling systems can shorten the life of the CHIP since the rapid increase of temperature to its maximum limit accompanied by slow heat removal requiring the component to be always operating at elevated temperatures

\section{REFERENCES}

1. Tan, F.L. and C.P. Tso, 2004. Cooling of mobile electronic devices using phase change materials. Applied Thermal Eng., 24: 159-169. DOI: 10.1016/j.applthermaleng.2003.09.005
2. Semiconductor Industry Association, 1999. The International Technology Roadmap for Semiconductors. http://www.siaonline.org/cs/papers_publications/press_release_de tail? pressrelease. $. \mathrm{id}=312$

3. AMD, 2008. AMD phenom ${ }^{\mathrm{TM}}$ model number and feature comparisons.

http://www.amd.com/us/products/desktop/processo rs/phenom/Pages/AMD-phenom-processor-modelnumbers-feature-comparison.aspx

4. Xserve, 2008. Xserve (Early 2008): Power consumption and thermal output (BTU) information.

http://support.apple.com/kb/TA25163?viewlocale= en_US

5. Vasiliev, L.L., 2005. Heat pipe in modern heat exchangers. Applied Thermal Eng., 25: 1-19. DOI: 10.1016/j.applthermaleng.2003.12.004

6. Bielinski, George, 2001. Thermoelectric cooling system. US Patent 6401462.

http://www.patentstorm.us/patents/6401462/descri ption.html

7. Melcor, 2004. Thermoelectric handbook. http://www.melcor.com/handbook.html

8. Dunn, P.D. and D.A. Reay, 1978. Heat Pipes. 2nd Edn., Pergamon Press, Oxford.

9. Legierski, J., B. Wiecek and G.D. Mey, 2006. Measurements and simulations of transient characteristics of heat pipes. Microelect. Reliabil., 46: 109-115. http://www.informatik.unitrier.de/ ley/db/journals/mr/mr46.html

10. Subramanyam, S. and K.E. Crowe, 2000. Rapid design of heat sinks for electronic cooling using computational and experimental tools. Proceedings 16th Annual IEEE Symposium on Semiconductor Thermal Measurement and Management, Mar. 2123, IEEE Xplore Press, San Jose, CA, USA., pp: 243-251. DOI: 10.1109/STHERM.2000.837090 